\title{
E-commerce untuk Penjualan Arang Tempurung berbasis Android
}

\author{
Suhardi Rustam ${ }^{\mathrm{a}, 1, *}$ dan Sumarni ${ }^{\mathrm{a}, 2}$ \\ ${ }^{a}$ Universitas Ichsan Gorontalo, Jln. Achmad Najamuddin, Kota Gorontalo dan Kode Pos 96115, Indonesia \\ ${ }^{1}$ suhardirstm@gmail.com; ${ }^{2}$ marnisiwa@gmail.com \\ *corresponding author
}

\section{INFORMASI ARTIKEL ABSTRAK}

Dikirim : 16 Oktober 2020

Diulas : :06 Desember 2020

Direvisi : 06 Desember 2020

Diterbitkan : 28 Desember 2020

\section{Kata Kunci:}

e-commerce

Arang Tempurung

Rapid Application Development (RAD)

Limbah Kelapa

Ekonomi Masyarakat
Pengolahan limbah kelapa di gorontalo utara umumnya diolah secara tradisional yang tidak jelas kualitasnya, sehingga menyebabkan keragaman olahan limba kelapa sangat tinggi. Penumpukan Limbah kelapa dan pengelolaan yang tidak memenuhi standar sehingga tidak memiliki nilai ekonomis bagi masyarakat. Pada permasalahan ini maka diperlukan adanya Pembinaan kepada para petani kelapa di gorontalo utara. Oleh karena itu menyajikan pembuatan aplikasi kepada petani kelapa dalam bentuk e-commerce yang mampu memberikan kemudahan menjual untuk para petani kelapa dengan tampilan yang menarik. $E$ commerce yang terdapat dalam bentuk aplikasi android, fokus penelitian untuk merancang e-commerce penjualan melalui handphone dalam memasarkan produk arang tempurung dari limbah kelapa. Sehingga pada penelitian ini ditemukan beberapa permasalahan yang menjadi fokus penelitian untuk menangani tentang kesulitan para petani kelapa memasarkan produk arang tempurung dari limbah kelapa dan masih banyak petani yang sulit memaksimalkan pemasaran di internet melalui handphone. Ruang lingkup penelitian ini adalah perancangan e-commerce dengan media internetnya adalah handphone, sehingga permasalahan pada penerapan e-commerce arang tempurung menjadi mudah untuk diimplementasikan. Hasil penelitian ini setelah perancangan e-commerce ini dapat membantu masyarakat untuk mengatasi kesulitan memasarkan produk turunan kelapa atau produk limbah kelapa yang telah memberikan nilai ekonomi dan sebagai sumber alternatif penghasilan ekonomi keluarga atau komunitas masyarakat pada aspek pemasaran digital.

\section{ABSTRACT}

The process of coconut waste in Gorontalo, the North in general is processed in the traditional quality is not clear, so the cause of the diversity of coconut waste processed is very high. Builders waste oil and management did not meet the standards that have no economic value to the community. In this issue need to guidance the existence of the coconut farmers in North Gorontalo. Therefore, it presents the creation of applications for coconut farmers in the form of ecommerce that can provide the ease of selling to the coconut farmers with an attractive appearance. E-commerce contained in the form of an android application, the focus of research to designing e-commerce sales via mobile in a shell products marketing of waste oil. So, in this study find some issues that become the focus of research to deal with the difficulties of farmers coconut products coconut shells coconut waste and still many farmers that it is difficult for a marketing on the internet through their mobile phones. The scope of this research is the design of e-commerce with media, internet on the move, so the problem is in the implementation of the shell of e-commerce will be easy to apply. The results of this study after the design of e-commerce can help the community to overcome the difficulties of marketing the products of derivatives of oil or waste products of the coconut that has been providing economic value and as a source of alternative income to the family economy or the community on the aspects of digital marketing.

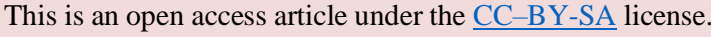




\section{Pendahuluan}

E-commerce merupakan sarana perdagangan yang dilakukan secara online melalui media elektronik. Hal ini merujuk pada arti yang lebih luas, selain itu e-commerce selain aktivitas pembelian dan penjualan produk serta tawaran jasa hal ini juga pelayanan kepada pelanggan, kerjasama terhadap kelompok pebisnis, e-learning dan transaksi dalam perusahaan [1]. Di negara Indonesia sendiri, aktivitas kegiatan $e$ commerce telah tertuang dalam perundang undangan dengan nomor 11 Tahun 2008 Tentang Internet dan Transaksi Elektronik. Dalam hal ini belum sepenuhnya secara keseluruhan mencakup segala perbuatan atau kegiatan serta aktivitas di online, akan tetapi telah cukup untuk dapat menjadi dasar atau landasan dalam melakukan aktivitas kegiatan bisnis online.

Tanaman Kelapa sebagai satu komoditas unggulan di tingkat nasional dan telah memiliki peranan penting dalam perekonomian Gorontalo Utara yang merupakan daerah tanaman kelapa dalam dengan produktivitas $1.480 \mathrm{Kg} / \mathrm{Ha}$ di Kab. Gorontalo utara dengan jumlah 112975 jiwa (BPS Gorontalo Utara, 2017)9[2]. Pengolahan limba kelapa oleh petani Gorontalo utara umumnya diolah secara tradisional yang tidak jelas kualitasnya, sehingga menyebabkan keragaman limbah kelapa sangat tinggi. Pengolahan limba kelapa yang tidak kualitasnya merupakan akar permasalahan rendahnya pemanfaatan nilai ekonomis limbah kelapa di Gorontalo utara. Untuk menjamin serta meningkatkan mutu limbah kelapa khususnya arang tempurung pada petani kelapa di Gorontalo utara maka diperlukan teknik khusus untuk meningkatkan mutu arang tempurung yang akan dikemas dalam e-commerce untuk pemasaran kepada para petani kelapa di Gorontalo utara serta melakukan pengembangan produk limbah kelapa.

Limbah Tempurung kelapa sebagai satu contoh yang dihasilkan dari limbah industri dan limbah pertanian atau biasa dikenal sebagai biomassa. Pemanfaatan limbah tempurung kelapa ini menjadi limbah yang dapat digunakan sebagai satu dari banyaknya sumber bahan bakar alternatif, dan selain itu dapat mengurangi banyaknya jumlah limbah yang di produksi baik oleh pabrik, juga dapat menghemat penggunaan bahan bakar fosil. Hasil dari pemanfaatan limbah tersebut dapat dijual secara luas sehingga memiliki nilai ekonomi yang lebih dan dapat membantu mengurangi peranan bahan bakar fosil dengan adanya bahan bakar alternatif ini.

Arang tempurung merupakan salah satu produk limbah kelapa yang di olah dengan cara pembakaran dalam sebuah wadah dari tanah atau drum. Pembakaran ini dipilih untuk membakar batok kelapa menjadi arang yang diatur dengan cara tradisonal. Dalam waktu 6 - 12 jam, arang tempurung sudah terbentuk. Selain itu, hasil olahan limbah berupa arang tempurung kelapa yang berbahan organik memiliki nilai kalor tinggi dan pembakarannya mampu bertahan lama serta mengandung karbon $\pm 70 \%$ sehingga arang tempurung kelapa sulit melakukan pembakaran pada tahapan awal. Tetapi, tempurung kelapa merupakan salah satu bahan karbon aktif yang kualitasnya lebih baik dijadikan arang aktif.

Limbah Kelapa memiliki banyak produk turunan yang sering diolah petani untuk dimanfaatkan sendiri atau dijual kembali untuk mendapatkan nilai ekonomi, banyaknya produk turunan limbah kelapa yang bernilai ekonomis seperti produk arang [3], selain produk ini memiliki peminat di pasar lokal juga penjualan produk arang sering dijumpai di pasar mingguan rakyat atau sering dijemput oleh pengepul arang dengan harga murah untuk dijual kembali selain itu produk turunan lain yaitu berbentuk arang tempurung[4] juga bisa berupa briket arang yang akan menaikan harga yang lebih ekonomis bagi petani. Harga pasar yang murah dan adanya produk turunan lain berupa bentuk briket arang menjadi fokus pertimbangan bagi peneliti untuk merancang digital pemasaran [5] melalui internet berbasis handphone dengan merancang e-commerce [6] briket arang tempurung dalam menangani kesulitan jual produk limbah kelapa [7] petani di provinsi Gorontalo Utara.

Hal ini didukung oleh faktor perangkat yang kebanyakan memiliki sarana mobile handphone yang selalu terkoneksi dengan internet [8]. Oleh karena itu, terbentuk ide dengan perangkat pendukung di lapangan untuk menyajikan pembuatan aplikasi kepada petani kelapa yang mampu memberikan kemudahan menjual[9] untuk para petani kelapa dengan tampilan yang optimal[10] dan aplikasi yang mendukung sistem operasi android. Aplikasi ini lebih dinamis dan cocok untuk digunakan di Handphone karena memiliki keunggulan dalam format gambar yang langsung dari kamera dengan tampilan yang menyesuaikan resolusi pixel kamera handphone agar mudah digunakan oleh para petani kelapa dalam mengupload gambar produk briket arang ke dalam database aplikasi.

Sehingga pada penelitian ini ditemukan beberapa permasalahan yang menjadi fokus penelitian untuk menangani tentang kesulitan [11] para petani kelapa memasarkan produk arang tempurung dari limbah kelapa dan masih banyak petani yang sulit memaksimalkan pemasaran di internet melalui handphone. Ruang lingkup penelitian ini adalah perancangan e-commerce [12] dengan media internetnya adalah handphone, sehingga permasalahan pada penerapan e-commerce arang tempurung menjadi mudah untuk diimplementasikan. Hasil penelitian ini setelah perancangan e-commerce ini dapat membantu masyarakat untuk mengatasi kesulitan memasarkan produk turunan kelapa atau produk limbah kelapa yang telah memberikan nilai ekonomi dan sebagai sumber alternatif penghasilan ekonomi keluarga atau komunitas masyarakat pada aspek pemasaran digital [13]. 


\section{Metode}

Pada penelitian ini menggunakan Model Pengembangan Rapid Application Development (RAD) yang dimulai fase Identifikasi Perencanaan tentang kebutuhan sistem dari informasi tentang masalah yang dihadapi untuk menentukan atau mengidentifikasi tujuan, adanya batasan-batasan sistem, kendala dan adanya alternatif pemecahan masalah, serta analisis yang digunakan dalam mengetahui perilaku sistem. Pada fase desain seperti harus mengidentifikasi solusi alternatif lain dan memilih adanya solusi yang terbaik, dan selanjutnya membuat desain proses bisnis dan desain serta konstruksi preprograming dari pemodelan notasi. Fase implementasi yaitu fase ke dalam bentuk yang bahasa program mesin yang diwujudkan dalam bentuk program atau unit-unit program. Adapun model pengembangan ini dapat dilihat paga Gambar 1.

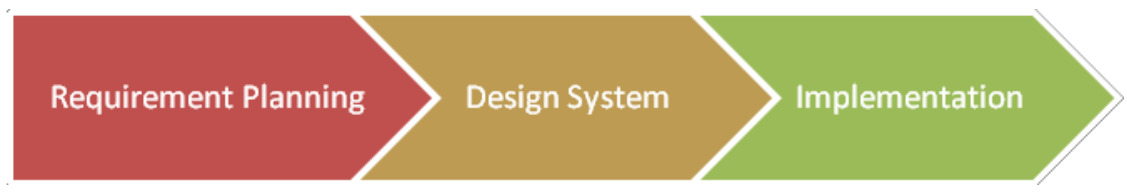

Gambar 1. Model Pengembangan sistem

Dalam karakteristik metode RAD [14] yang memiliki alur cepat dan singkat, dapat memungkinkan pemrograman memilih beberapa aplikasi Content Management System [15] dalam rangka pembangunan web e-commerce [16]. Dimana CMS menghasilkan penghematan dan memiliki penyediaan cara yang efesien untuk memberikan isi dan ide dengan cara mengurangi biaya dan penyesuaian isi konten juga memastikan akurasi isi kontent dengan dengan penyetujuan dalam proses arus kerja. Pada tahapan tersebut adalah sebagai berikut:

Hal-hal yang perlu dilakukan pada tahapan metode RAD

a. Tahapan pertama, Rencana Kebutuhan (Requirement Planning): tahapan ini pengguna dan penganalisa melakukan koordinasi pertemuan untuk mengenali tujuan dari sistem dan kebutuhan informasi untuk capaian tujuan bersama. Pada tahap ini menjadi penting dengan adanya keterlibatan dari masingmasing pihak.

b. Tahapan kedua, Proses Desain Sistem (Design System): Pada tahap ini diperlukan keaktifan pengguna yang terlibat menentukan capaian tujuan bersama, pada proses ini melakukan aktivitas proses desain dan melakukan perbaikan yang masih terdapat ketidaksesuaian desain antara pengguna dengan penganalisis. Seorang pengguna dapat langsung memberikan penjelasan pendapat apabila terdapat ketidaksesuaian pada desain, merancang sistem dengan mengacu pada dokumentasi kebutuhan pengguna yang sudah dibuat pada tahapan sebelumnya. Hasil akhir dari tahapan ini adalah spesifikasi software yang melingkupi sistem organisasi secara umum, struktur data dan yang lainnya.

c. Tahapan Ketiga, Implementasi (Implementation): pada tahapan ini yaitu tahapan programmer yang mengkonstruksi desain suatu program yang telah disetujui oleh pengguna dan penganalisis. Sebelum dipakai pada suatu organisasi maka harus dahulu dilakukan proses pengujian setiap unit-unit program. Pada tahap ini pengguna akan memberikan tanggapan terhadap sistem yang telah dibuat serta mendapat penyetujuan mengenai sistem tersebut.

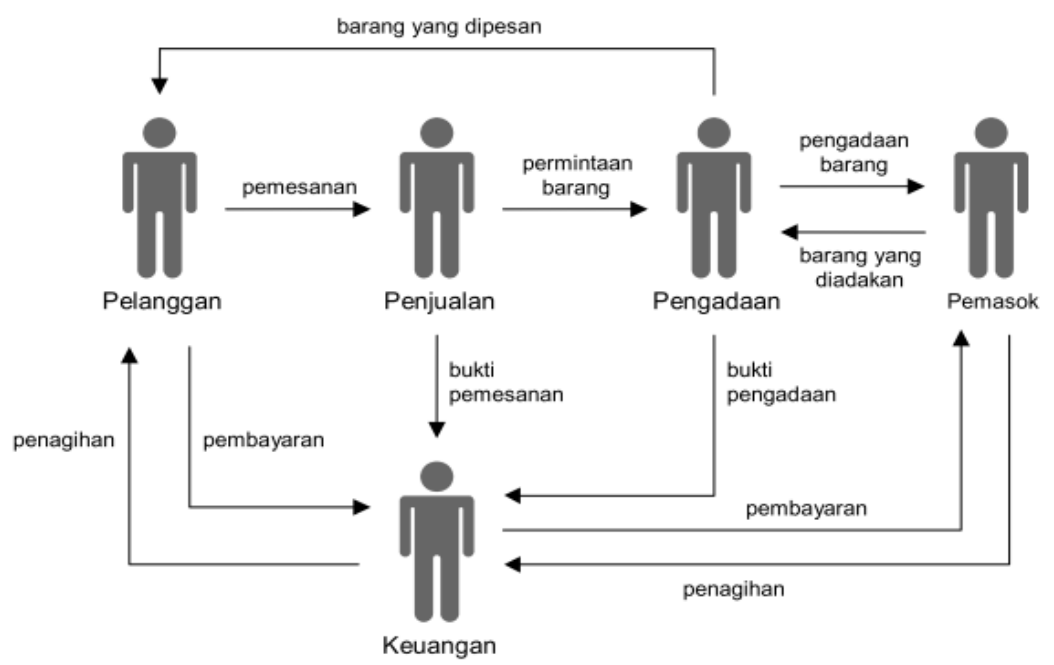

Gambar 2. Prosedur Kerja Penjualan 
Gambar 2 adalah alur prosedur kerja penjualan pada aplikasi penjualan online arang tempurung, gambar tersebut untuk memetakan alur kerja masing-masing dari aktor yang terlibat dalam sistem penjualan online pada e-commerce.

\section{Hasil dan Pembahasan}

Perancangan aplikasi e-commerce ini dapat digunakan untuk memulai memasarkan produk briket arang tempurung sehingga aktivitas alternatif masyarakat dapat membantu untuk mengatasi kesulitan pemasaran produk turunan kelapa atau daur ulang limbah kelapa yang memiliki nilai ekonomis. Selain melakukan evaluasi dan tensting untuk mengurang tingkat kesalahan bentuk program tetap menggunakan model pengujian dengan black box testing.

Pada aplikasi ini pada tahap selanjutnya akan dikembangkan fitur-fitur sesuai kebutuhan pembeli dan penjual yang dapat memantau kemudahan yang didapatkan oleh minat masyarakat. Aplikasi $e$ commerce ini agar mampu mampu memberikan kemudahan menjual untuk para petani kelapa dengan tampilan yang menarik. E-commerce terdapat dalam bentuk aplikasi android. Aplikasi ini lebih difokuskan untuk digunakan di Handphone karena memiliki keunggulan dalam format gambar yang langsung dari kamera dengan tampilan yang menarik agar mudah digunakan oleh para petani kelapa dalam mengolah limbah kelapa Gorontalo Utara.

\section{A. Tahapan Planning}

Pada tahapan planning itu mengidentifikasi Kebutuhan sistem dan penyesuaian aktor-aktor dalam sistem yang terlibat. seperti Admin, Pelanggan, Penjualan, Pengadaan, Pemasok, Keuangan, Manager. Adapun proses bisnis dapat dilihat pada Gambar 3.

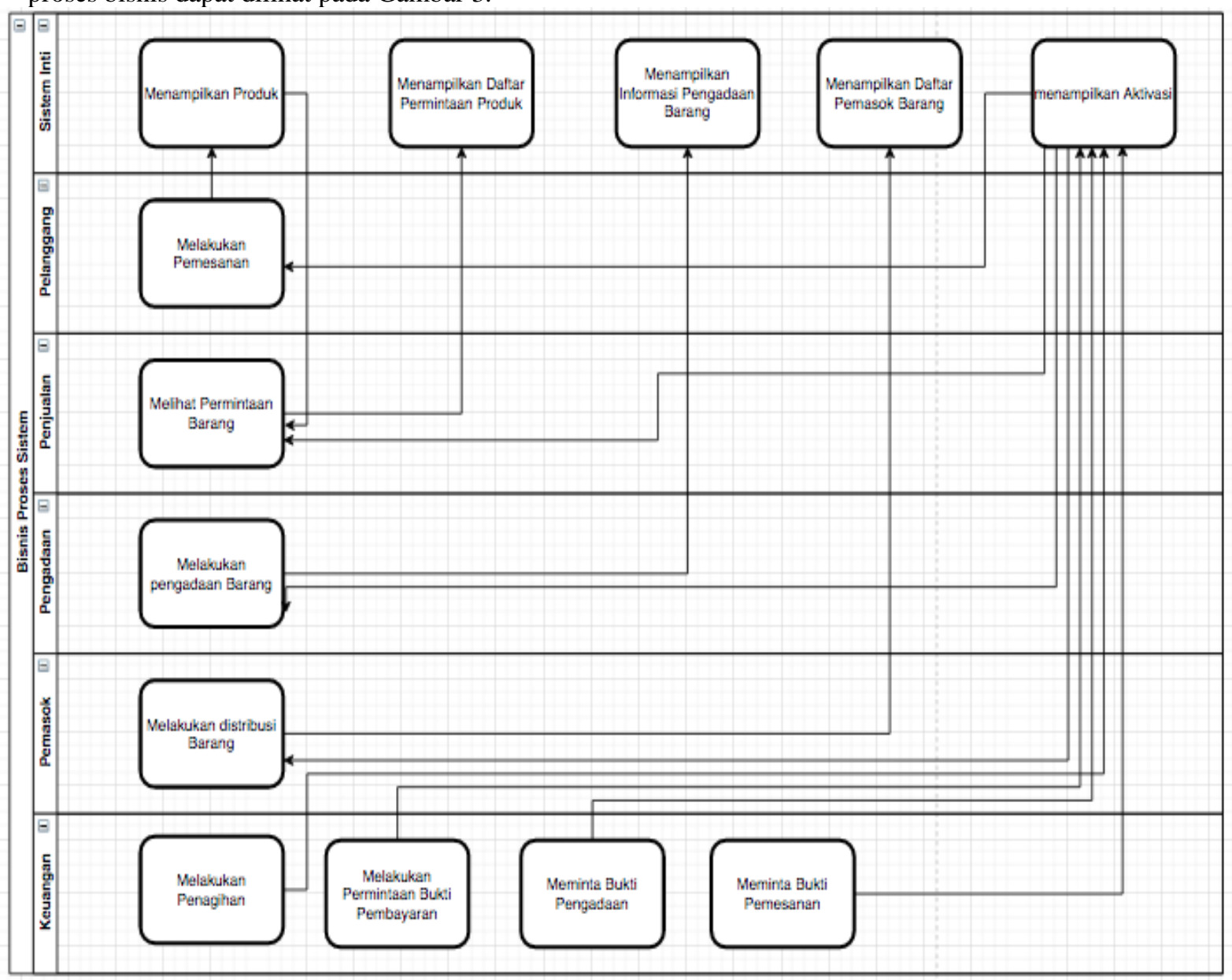

Gambar 3. Bisnis Proses Sistem Penjualan

Gambar 3 merupakan tampilan atau skema bisnis proses sistem penjualan yang menggambarkan keterhubungan aktivitas-aktivitas setiap entitas yang memiliki tugas masing-masing. 


\section{B. Tahapan Analisis dan Desain}

1. Analisa Sistem dengan Use Case Diagram

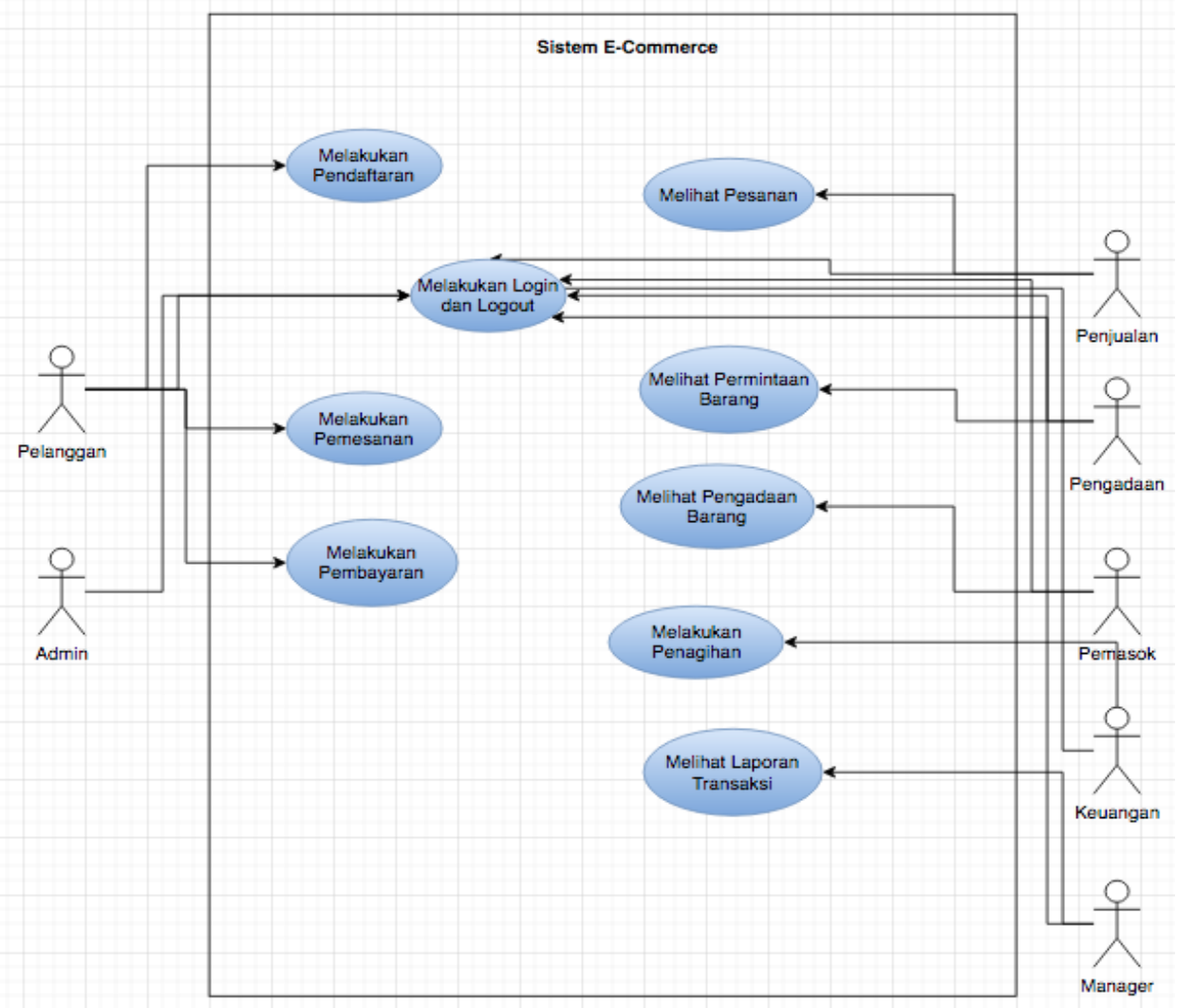

Gambar 4: Use Case Penjualan

Use case penjualan yang digambarkan pada Gambar 4 merupakan tampilan keseluruhan sistem dan aktor yang terlibat. Tampilan use case ini akan mempermudah dalam menganalisa sistem dalam pembuatan aplikasi secara keseluruhan

\section{Desain Activity Diagram}

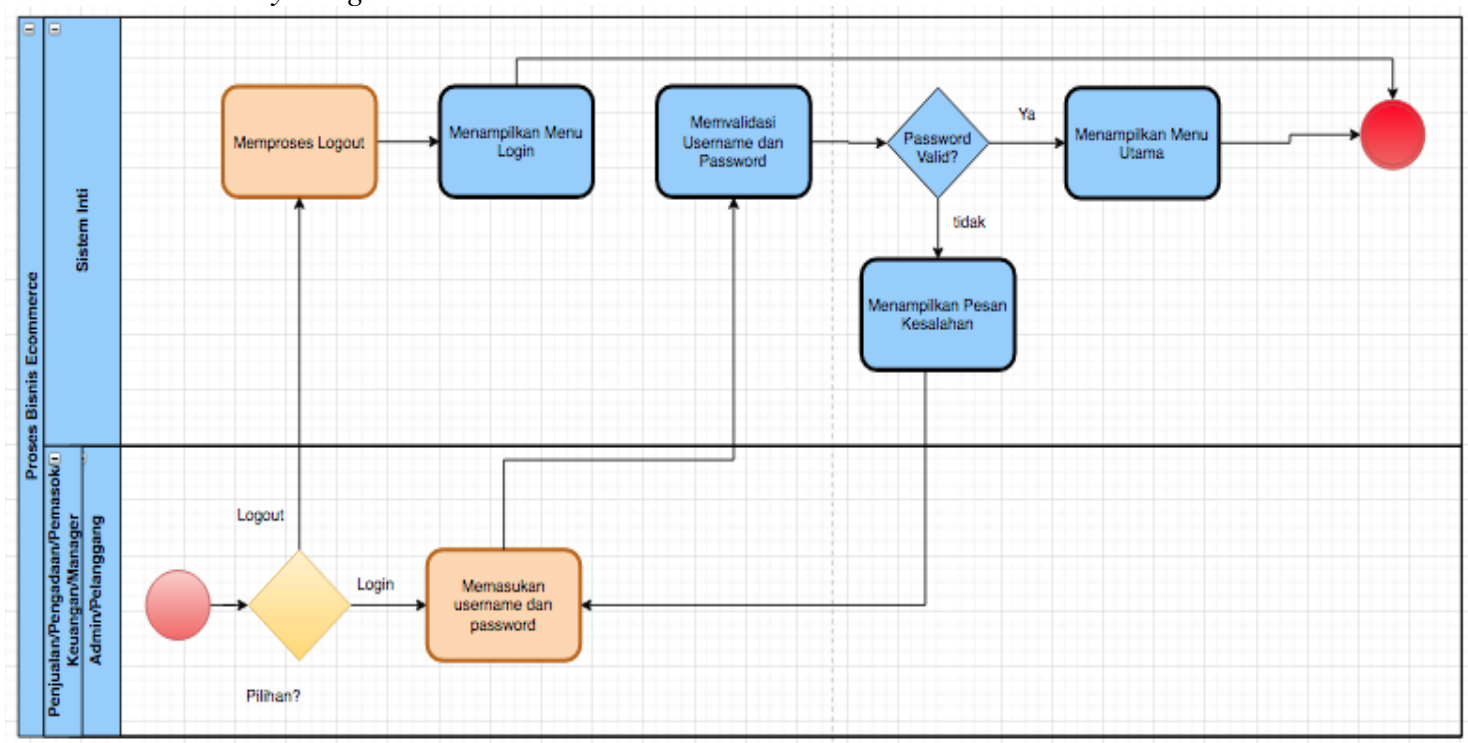

Gambar 5. Activity Diagram

Gambar 5 merupakan proses verifikasi bagi penguna untuk masuk ke dalam sistem atau sebaliknya yang dikenal dengan aktivitas login/logout. 
3. Desain Sequence Diagram

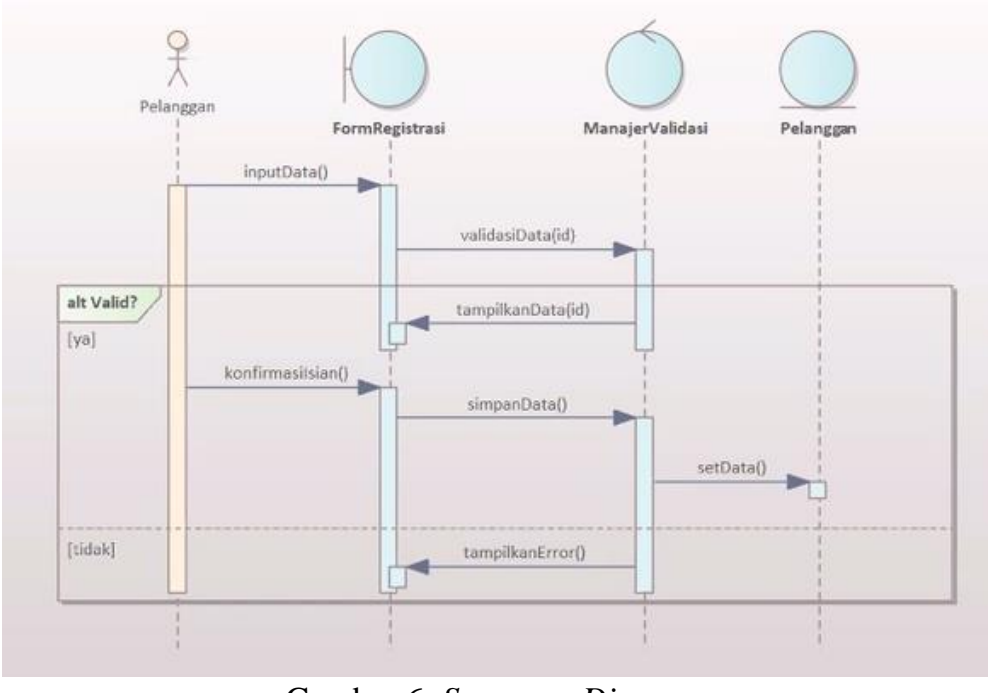

Gambar 6. Sequence Diagram

Pada tahapan sequence diagram seperti pada Gambar 6 merupakan tahapan yang menjelaskan tentang interaksi entitas terhadap sistem pada saat mengeksekusi perintah.

\section{Tahapan Desain}

1. Class Diagram

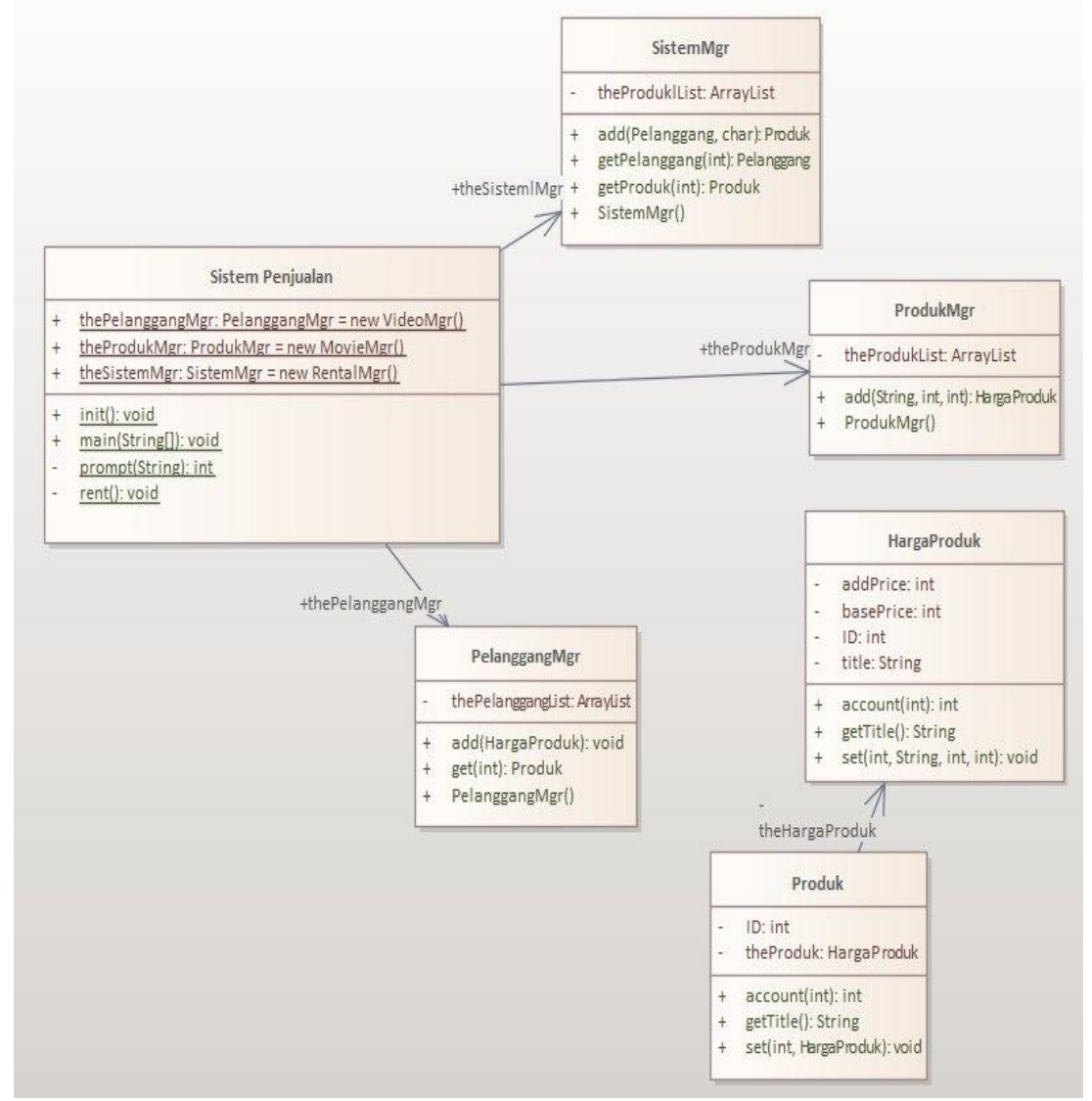

Gambar 7. Class Diagram Sistem Penjualan

Pada Gambar 7 menjelaskan alur yang berjalan pada database untuk sistem penjualan yang lebih dikenal dengan class diagram. 


\section{Desain User Interface}
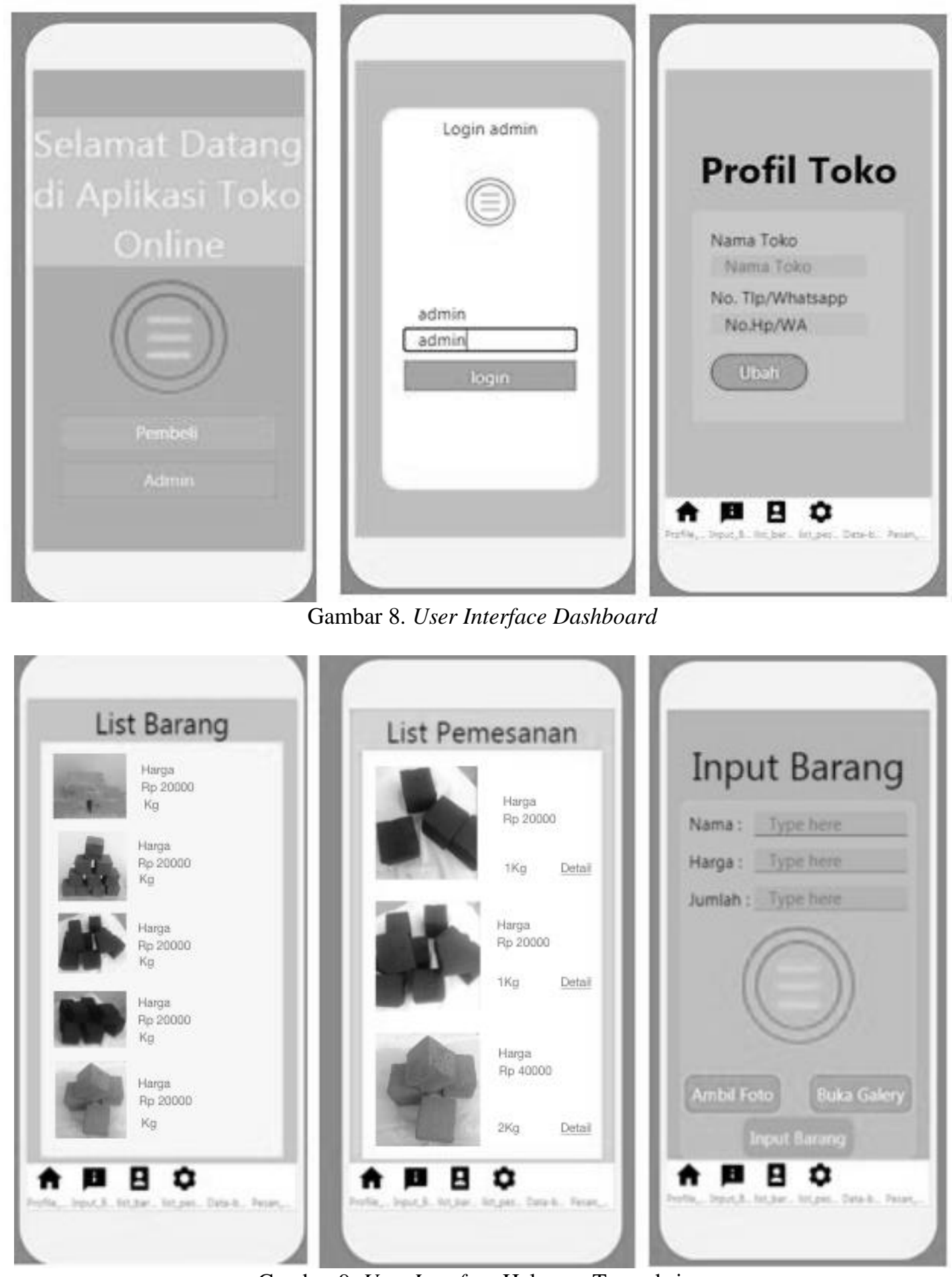

Gambar 9. User Interface Halaman Transaksi

Gambar 8 adalah tampilan aplikasi penjualan dengan model mobile phone untuk tampilan aktivitas pengguna sebagai pembeli dan administrator, serta pada Gambar 9 menunjukan halaman utama untuk pengguna sebagai pembeli.

\section{Tahapan Implementasi}

Pada tahapan konstruksi system adalah tahapan pembuatan program berdasarkan acuan pada sekuensi diagram dimana akan dimulai pada aktivitas actor yang terlibat, boundary system yang terbentuk, control model dan entity kelas yang ada dan kemudian melanjutkan untuk konstruksi program atau uni program. 


\section{Kesimpulan dan saran}

Perancangan e-commerce ini dapat membantu masyarakat untuk mengatasi kesulitan memasarkan produk turunan kelapa atau produk limbah kelapa yang telah memberikan nilai ekonomi dan sebagai sumber alternatif penghasilan ekonomi keluarga atau komunitas masyarakat pada aspek pemasaran digital. Adapun saran dalam penelitian ini adalah diperlukannya pendampingan kepada masyarakat dalam penggunaan fiturfitur aplikasi ini dan diperlukan kerjasama terhadap desa, dinas terkait untuk memberikan penyesuaian aplikasi ini sehingga menjadi point-point kebijakan yang mendukung kesejahteraan masyarakat.

\section{Terima Kasih}

Ucapan terima kasih kepada Ristekbrin/DPRM dan untuk seluruh rekan peneliti di Universitas Ichsan Gorontalo yang telah memberikan bimbingannya, khusus rekan sesama peneliti di Lembaga Penelitian (LEMLIT) Universitas yang selalu memberikan bimbingan teknis dan untuk dosen dan peneliti di fakultas ilmu komputer yang siap bekerjasama untuk meningkatkan kemampuan penulisan artikel ilmiah.

\section{Daftar Pustaka}

[1] A. Adwihardja, 2016, e-commerce sebagai model inovasi teknologi strategi enterpreneur menurut preferensi pengguna jakartanotebook.com, Bina Insani Ict Journal, Vol.3, No.1, hal $154-163$

[2] (BPS) Badan Pusat Statistik Gorontalo Utara, 2018, Laporan publikasi 2018, https://gorontaloutarakab.bps.go.id/publication.html, diakses tanggal 12 Agustus 2018

[3] Nustini, Y., \& Allwar, A. (2019). Pemanfaatan Limbah Tempurung Kelapa Menjadi Arang Tempurung Kelapa dan Granular Karbon Aktif Guna Meningkatkan Kesejahteraan Desa Watuduwur, Bruno, Kabupaten Purworejo _ Nustini _ Asian Journal of Innovation and Ent. Asian Journal of Innopation and Enterpreneurship, 4(3), 217-226.

[4] S. K. Maya, 2011, potensi dan kelayakan ekspor arang tempurung kelapa, jurna ilmu pertanian, volume 7 no 12, 2011: hal 69-82

[5] Budi, D. S., Siswa, T. A. Y., \& Abijono, H. (2017). Analisis Pemilihan Penerapan Proyek Metodologi Pengembangan Rekayasa Perangkat Lunak. Teknika, 5(1), 24-31. https://doi.org/10.34148/teknika.v5i1.48

[6] K. Riset and D. A. N. P. Tinggi, 2017, "Riset Nasional Tahun 2017-2045 (Edisi 28 Pebruari 2017)," vol. 2045.

[7] R. Rahmadi. 2010. Studi Komparatif Penggunaan Open-Source Content Management System (CMS) Joomla dan Drupal Untuk Pembuatan Website. Jurnal Generic. Vol.5, No. 1.

[8] W. Tenia, 2014, Perancangan WEB e-commerce dengan Metode Rapid Application Development (RAD) untuk Produk Unggulan Desa, Jurnal Seminar nasional Teknologi Informasi dan Komunikasi Semarang, vol 9, hal 81-88

[9] S. Pringsewu, 2017, "Penerapan e-commerce berbasi Business to Consumers untuk Meningkatkan Penjualan Produk," vol. 15, no. 2, pp. 109-116.

[10] E. Rapha and T. Nursalim, 2016, "Analisis Jalur Pengaruh Kepercayaan Konsumen dan Desain Website terhadap Minat Beli Ulang, dengan e-check secara Online," vol. 1.

[11] Edwin Agung Wibowo,2015, "Pemanfaatan Teknologi e-commerce dalam Proses Bisnis" pp. 95-108.

[12] G. Indah, P. S. Yanti, and S. Hajratul, 2020, "Pengaruh Independensi dan Bisnis E-commerce Terhadap Kebutuhan Jasa Audit E-commerce," vol. 04, no. 01, pp. 25-32

[13] Y. Windarto, (2016). Pengaruh Usability Factor Website E-commerce Model B2C Terhadap Kepercayaan User. Jurnal Sistem Informasi (JSI), 8(2), 1106-1120.

[14] J. R. Sagala. (2018). Model Rapid Application Development (Rad) Dalam Pengembangan Sistem Informasi Penjadwalan Belajar Mengajar. Jurnal Mantik Penusa, 2(1), 87-90.

[15] J. Herawati, L. Tria, H. Hutami, and P. P. Sari, 2019, "Pelatihan Kewirausahaan Pembuatan dan Promosi," vol. 2, no. 1, pp. 1-7.

[16] T. Pradiani, V. Penjualan, and S. Malang, 2017, “Terhadap Peningkatan Volume Penjualan Hasil,” vol. 11, pp. 46-53, 2017. 